\title{
EVALUATION STUDY OF EUCHEUMA COTTONII SPECIES OF SEAWEED CULTIVATION BASED ON OCEANOGRAPHIC PARAMETERS IN PASIEA, BONEGUNU SUBDISTRICT, NORTH BUTON DISTRICT
}

\author{
Abdilah Salihin ${ }^{1}$, Amir Hamzah Muhiddin², Inayah Yasir ${ }^{3}$ \\ Submitted: July 14, 2019, Accepted: September 20, 2019
}

$1,2,3$ Department of Marine Science, Faculty of Marine Science and Fisheries, University of Hasanuddin
J1. Perintis Kemerdekaan Km. 10 Makassar 90245
Corresponding Author:
Amir Hamzah Muhiddin
Email. amirhm.unhas@gmail.com

\section{ABSTRACT}

This study aims to determine the level of land suitability and the area of Eucheuma cottonii in Pasiea waters, to know the dynamics and correlation of oceanographic parameters towards the growth of E. cottonii seaweed. This research was conducted in August-October 2018 in the area of seaweed cultivation in Pasiea waters. The observation station consisted of six stations located in the area of seaweed cultivation. Oceanographic parameters dynamics were measured by oceanographic parameters measured which significantly affected the growth of seaweed species $E$. cottonii in the form of temperature, salinity, brightness, depth of flow, current velocity, nitrate, and phosphate has been mentioned before which wasthen overlaid on the map maker application to produce a map of the suitability level of $E$. cottonii seaweed cultivation in Pasiea waters. The results of the spatial analysis showed that the level of Pasiea waters suitability based on oceanographic parameters was in the less suitable category covering 1410 ha and did not match $1 \mathrm{Ha}$, whereas based on the daily growth rate of $E$. cottonii the overall research locations were in the excellent category of 1411 ha. The dynamics of oceanographic parameters were still within the range that can be tolerated for the growth of $E$. cottonii with parameters that correlate to the daily growth rate of salinity, brightness, phosphate, and nitrate.

Keywords: Seaweed cultivation, E. cottonii, Oceanographic parameters

\section{INTRODUCTION}

The potential for developing seaweed cultivation in Indonesia is huge. This is supported by the availability of vast land, high diversity of seaweed, simple cultivation technology, and relatively small capital needed. This can be relied upon as one of the fishery products that can improve the standard of living of coastal communities whose economic and educational conditions are still relatively low (Santoso and Yudha, 2008). The success of seaweed cultivation can be determined by the conditions of oceanographic parameters and growth rates so that this becomes a matter that must be considered in the process of seaweed cultivation (Hermawan, 2015).

North Buton Regency has waters that have the potential to be developed as seaweed cultivation, one of which is in Pasiea Waters which has been used as the location for E. cottonii cultivation since year 2000. In 2016, seaweed production in Bonegunu District alone amounted to 688.35 tonnes (BPS North Buton Regency, 2017). According to local farmers, different growth rate had been observed among location and the value depends on planting season.

There was even a decrease in crop yields for certain time which causing crop failure. The ordeal was allegedly due to location mismatches for certain seasons and times. This condition is thought to be due to fluctuations in oceanographic parameters that affect the growth rate of E. cottonii seaweed. The purpose of this study was to determine the suitability of area for seaweed cultivation.

\section{MATERIALS AND METHODS}

This research was conducted in August to October 2018 for 40 days in Pasiea Waters, Bonegunu SubDistrict, North Buton Regency, which is one of the locations for E. cottonii cultivation. Determination of stations is based on differences in characteristics between the spot of the cultivation location used. The preliminary data was compare to the information on seaweed yields at the same season from previous years. The GPS coordinates for each location were recorded. The seeds used weighed 50 grams, weighed using a digital hanging scales with a precision level of 0.1 grams. This distance is chosen as the local farmers commonly do. The seeds were tied to a 42-meter stretch with a distance of $\pm 13 \mathrm{~cm}$ between seeds, which made up to 320 seedlings for each stretch. Requirements for sampling at least $10 \%$ of the total population. This means that there are 32 randomly selected seedlings in each location that will represent the location and will be weighed for every 10 days. There were 12 stretches of rope spread between the stretch of seaweed farmers' ropes on six pens tied to anchor ropes which were adjusted to the depth of the seaweed cultivation location. This stretch was maintained at a depth of $\pm 30 \mathrm{~cm}$ from the surface of the sea by using 6-7 used plastic bottles for each rope. The bottles serves as a buoy that lifts the thallus so that the rope remained perfectly stretched. 
Data was collected in the field for one planting period (40 days), with five data collection times, each with 10-day intervals. For each interval 10 days, the data taken was oceanographic parameter data (temperature, salinity, water depth, brightness, current velocity, nitrate, and phosphate) and seaweed weights. Oceanographic parameter data was taken in the field, except for salinity, nitrate and phosphate levels (Darmawati et al., 2016; Sirajuddin, 2009). The 32 seaweed seedlings that had been marked were weighted (Serdiati and Widiastuti, 2010). The measurement of oceanographic parameters were done at the same time for each stasiun. Stasiun 1 at 08:00 WITA, stasiun 2 at 09:00, stasiun 3 at 10:00, stasiun 4 at 15:00, while stasiun 5 and 6 at 16:00 WITA and 17:00 WITA respectively.

\section{Data analysis}

Field data collected in the form of points (information) containing information on water quality measured, which then referred to the feasibility of oceanographic parameters for seaweed cultivation waters based on several sources (Table 1). The conformity assessment system for seaweed cultivation locations from Jailani et al. (2015) was modified (Table 2) in order to do the spatial analysis of the points.

Table 1. The feasibility of ocenographic parameters for seaweed cultivation based on several sources

\begin{tabular}{|c|c|c|c|c|}
\hline \multirow{2}{*}{$\begin{array}{l}\text { Parameters } \\
\text { (units) }\end{array}$} & \multicolumn{3}{|c|}{ Criteria } & \multirow[t]{2}{*}{ Reference } \\
\hline & $\mathrm{S} 1$ (5) & S2 (3) & $\mathrm{N}(1)$ & \\
\hline $\begin{array}{l}\text { Nitrate } \\
(\mathrm{mg} / \mathrm{l})\end{array}$ & $0.9-3.2$ & $\begin{array}{c}0.7-0.8 \\
\text { and } 3.3- \\
3.4\end{array}$ & $\begin{array}{l}<0.7 \\
\text { and } \\
>3.4\end{array}$ & $\begin{array}{l}\text { Selamat } e t \\
\text { al., 2015 in } \\
\text { DKP (2002) } \\
\text { and SK } \\
\text { Meneg LH } \\
\text { No. 51 } \\
(2004)\end{array}$ \\
\hline $\begin{array}{l}\text { Phosphate } \\
(\mathrm{mg} / \mathrm{l})\end{array}$ & $0.2-0.5$ & $0.51-0.7$ & $\begin{array}{l}<0.2 \\
\text { and } \\
>0.7\end{array}$ & $\begin{array}{l}\text { Selamat } e t \\
\text { al., } 2015 \text { in } \\
\text { Romimohart } \\
\text { o (2003) }\end{array}$ \\
\hline $\begin{array}{l}\text { Temperatur } \\
\text { e }\left({ }^{\circ} \mathrm{C}\right)\end{array}$ & $26-29$ & $30-33$ & $\begin{array}{l}<26 \\
\text { and } \\
>33\end{array}$ & $\begin{array}{l}\text { Syamsuddin } \\
\text { (2014) }\end{array}$ \\
\hline $\begin{array}{l}\text { Salinity } \\
\text { (PPT) }\end{array}$ & $28-31$ & $32-34$ & $\begin{array}{l}<28 \\
\text { and } \\
>34\end{array}$ & $\begin{array}{l}\text { SNI 7579.2 } \\
(2010)\end{array}$ \\
\hline $\begin{array}{l}\text { Brightness } \\
\text { (m) }\end{array}$ & $>3$ & $1-3$ & $<1$ & $\begin{array}{l}\text { Sirajuddin } \\
\text { (2009) }\end{array}$ \\
\hline Depth (m) & $1-10$ & $11-15$ & $\begin{array}{l}<1 \text { and } \\
>15\end{array}$ & $\begin{array}{l}\text { Sirajuddin } \\
\text { (2009) }\end{array}$ \\
\hline $\begin{array}{l}\text { Current } \\
\text { speed }(\mathrm{m} / \mathrm{s})\end{array}$ & $\begin{array}{c}0.20- \\
0.40\end{array}$ & 0.10-.19 & $\begin{array}{l}<0.10 \\
\text { and } \\
>0.40\end{array}$ & $\begin{array}{l}\text { Syamsuddin } \\
\text { (2018) }\end{array}$ \\
\hline
\end{tabular}

To determine the suitability of an area for seaweed cultivation based on environmental conditions, criteria were needed as a reference for determining the feasibility of the waters. Each parameter was grouped into 3 categories (classes), which were very suitable categories (S1), less suitable (S2), and not suitable (N) (Table 1).

Locations would be declared to be in the S1 category (very suitable) if the land did not have meaningful boundaries to maintain the process that applied. The status of location would be put in the $\mathrm{S} 2$ category (less suitable), if the land had a barrier but within the range that can still be tolerated to maintain the process applied. The status of location would be put in group $\mathrm{N}$ (not suitable), if the results of the assessment had a strong limiting factor, which greatly affected the quality of the water. This condition does not allow for the development of seaweed cultivation (Avianti et al., 2015).

The conclusion of the feasibility study of the location (station), the sum of the final value (Y) of all parameters at the station measured.

$$
Y=\sum_{i}^{n}\left(\frac{\text { weight }}{\text { maximum score of class }}\right) \times 100 \%
$$

The suitability value of each observation location was obtained by using the equation from Sirajuddin (2009)

$$
\begin{aligned}
& \text { range of class }(X) \\
& =\frac{\left(\sum \text { maximum value }\right)-\left(\sum \text { minumum value }\right)}{\text { number of class }}
\end{aligned}
$$

Where;

Determination of land suitability for seaweed cultivation was known after all oceanographic data was overlaid in the map maker application to produce thematic maps of the suitability of seaweed cultivation land in Pasiea waters (Hasnawi et al., 2013).

The effect of oceanographic parameters dynamics as measured by seaweed growth data was seen by conducting correlation tests using data processing applications (Wulandari et al., 2015).

The correlated data used the assumption that the content of oceanographic parameters in the previous day's measurements was correlated with the seaweeds growth rate data on the following day's measurement. in other words, the level of oceanographic parameters that day would affect the seaweeds growth rate in the next day. 
Table 2. The conformity assessment system for the location of seaweed cultivation, modified from Jailani et al. (2015).

\begin{tabular}{|c|c|c|c|c|}
\hline Parameter & Range & $\begin{array}{l}\text { Rating } \\
\text { Score } \\
\text { (A) }\end{array}$ & $\begin{array}{l}\text { Weight } \\
\text { (B) }\end{array}$ & $\begin{array}{l}\text { Score } \\
(\mathrm{AxB})\end{array}$ \\
\hline \multirow{3}{*}{ Nitrate (mg / l) } & $0.9-3.2$ & 5 & \multirow{3}{*}{3} & 15 \\
\hline & $\begin{array}{c}0.7-0.8 \text { and } \\
3.3-3.4\end{array}$ & 3 & & 9 \\
\hline & $\begin{array}{c}<0.7 \text { and } \\
>3.4\end{array}$ & 1 & & 3 \\
\hline \multirow{3}{*}{$\begin{array}{l}\text { Phosphate (mg / } \\
\text { 1) }\end{array}$} & $0.2-0.5$ & 5 & \multirow{3}{*}{3} & 15 \\
\hline & $0.51-0.7$ & 3 & & 9 \\
\hline & $\begin{array}{c}<0.2 \text { and } \\
>0.7\end{array}$ & 1 & & 3 \\
\hline \multirow{3}{*}{$\begin{array}{l}\text { Temperature } \\
\text { (oC) }\end{array}$} & $26-29$ & 5 & \multirow{3}{*}{3} & 15 \\
\hline & $30-32$ & 3 & & 9 \\
\hline & $\begin{array}{c}<26 \text { and } \\
>32\end{array}$ & 1 & & 3 \\
\hline \multirow{3}{*}{ Salinity (PPT) } & $28-31$ & 5 & \multirow{3}{*}{3} & 15 \\
\hline & $32-34$ & 3 & & 9 \\
\hline & $\begin{array}{c}<28 \text { and } \\
>34\end{array}$ & 1 & & 3 \\
\hline \multirow{3}{*}{ Brightness (m) } & $>3$ & 5 & \multirow{3}{*}{2} & 10 \\
\hline & $1-3$ & 3 & & 6 \\
\hline & $<1$ & 1 & & 2 \\
\hline \multirow{3}{*}{ Depth (m) } & $1-10$ & 5 & \multirow{3}{*}{2} & 10 \\
\hline & 11-15 & 3 & & 6 \\
\hline & $<1$ and $>15$ & 1 & & 2 \\
\hline \multirow{3}{*}{$\begin{array}{l}\text { Current } \\
(\mathrm{m} / \mathrm{s})\end{array}$} & $0.20-0.40$ & 5 & \multirow{3}{*}{2} & 10 \\
\hline & $0.10-0.19$ & 3 & & 6 \\
\hline & $\begin{array}{c}<0.10 \text { and } \\
>0.40\end{array}$ & 1 & & 2 \\
\hline \multicolumn{2}{|c|}{ Maximum Total Score } & & & 90 \\
\hline
\end{tabular}

Daily Growth Rate (DGR) was obtained by weighing wet seaweed seeds every 10 days. The daily growth rate was calculated using the equation from Huisman (Dawes et al., 1993 in Syamsuddin \& Misbah, 2018)

$$
\operatorname{DGR}(\% / \text { day })=\operatorname{Ln}\left[\frac{W_{t}-W_{0}}{t} \times 100 \%\right]
$$

DGR: Average specific growth rate (\% / day)

$\mathrm{W}_{\mathrm{t}}$ : Average weight of seaweed at each measurement (gram) $\mathrm{W}_{0}$ : Average weight of seaweed at the beginning of planting (gram)

t: Observation period (days)

The absolute growth of seaweed was observed from the beginning to the end of the study using the absolute growth formula;

$$
G=W_{t}-W_{0}
$$

G: Average absolute growth (grams)

Wt: Seaweed weight at the end of the study (gram)

W0: Weight of seaweed at the beginning of the study (gram)

The feasibility of seaweed cultivation based on the daily growth rate of seaweed measured for 40 days was divided into three categories, namely very good, good, and not good. The Very Good category will be given if the seaweeds daily growth rate (DGR) > $4 \% /$ day, Good if the daily growth rate is $3-4 \% /$ day, and the category was selected as Not Good if the daily growth rate was <3\%/day (WWF-Indonesia Fisheries
Team (2014); Ariyati et al., (2007) and Hernanto et al., (2015)).

\section{RESULTS AND DISCUSSION}

\section{Seaweed Growth}

Seaweed is stated to grow when there is an increase in its total weight. Based on the seaweed weights after 40 days, all seaweed in all station had been grown. The highest daily growth rate (DGR) of E. cottonii for all observation stations occurred at day 20, then declined further to the end of day 40. The highest DGR for day 20 was found in Station_5 (7.61\% / day) while the lowest happen at Station 2 (6.29\% / day) (Figure 1). The highest DGR value was found in Station_5 (6.99\% / day), while the lowest was found at Station 4 (5.41\% / day) (Figure 1). There was a pattern of increasing the same daily growth rate throughout the station until day 20 of observation (H20). This condition was in line with the results of Rehena (2009) and Hermawan (2015) who found an increase in the daily growth rate at the beginning of the observation. This condition was thought to be caused by competition between thallus in obtaining nutrients to grow.

During maintenance period, all seaweeds were increased in weight, except the seaweeds at station 4, which decrease in weight on the last $d$ ay of observation (H40). This incident is thought to have occurred due to the high salinity and temperature at this station which triggered the occurrence of ice-ice disease. All thallus turn white in colour and broken.

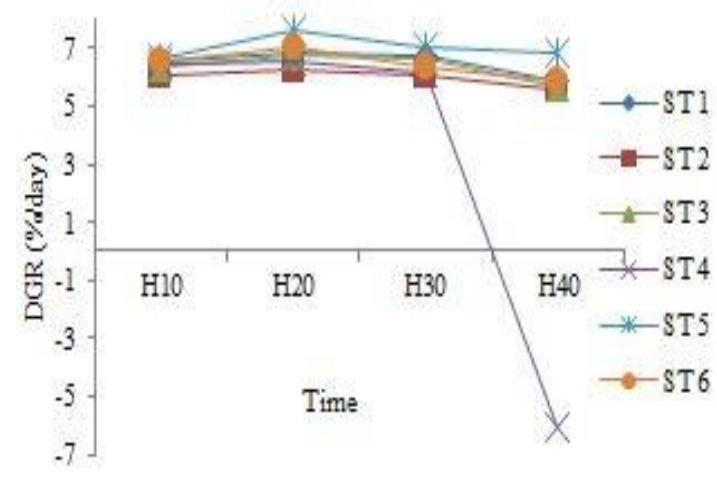

Figure 1 . Daily growth rate (DGR) of E. cottonii every 10 days observation for 40 days. Oceanographic Parameters

During the observation, there was a small daily fluctuation on oceanographic parameters, as well as during the study (Figure 2). Salinity and temperature experienced a pattern of increase during the study due to the high intensity of solar radiation which caused evaporation and increased the salinity and water temperature. Brightness, water depth, and current speed were fluctuated during tidal. During the study, the overall oceanographic parameters were still within the tolerance limit for the growth of E. cottonii seaweed. 

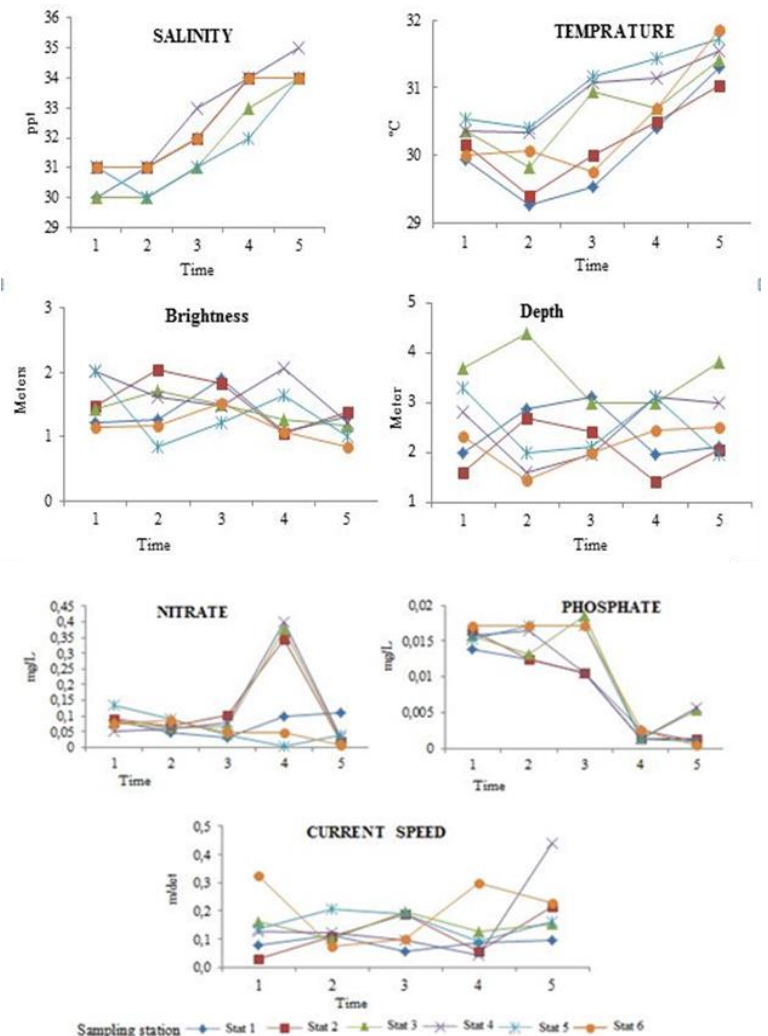

Figure 2. Graph of measurement results of oceanographic parameters

\section{Correlation Test of Daily Growth Rate with Oceanographic}

The correlation between measured oceanographic parameters and the daily growth rate (DGR) was evaluated to determine the dynamic relations (Table 3).

Table 3. The results of the correlation test between oceanographic parameters with daily growth rate (DGR) of seaweed type E. cottonii

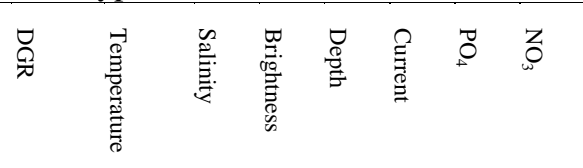

\begin{tabular}{|c|c|c|c|c|c|c|c|c|c|}
\hline \multirow{8}{*}{ 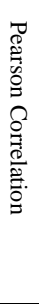 } & DGR & 1.000 & & & & & & & \\
\hline & Temperature & -.147 & 1.000 & & & & & & \\
\hline & Salinitys & -.654 & .375 & 1.000 & & & & & \\
\hline & Brightness & -.367 & -.097 & -.062 & 1.000 & & & & \\
\hline & Depth & -.081 & -.035 & -.219 & .495 & 1.000 & & & \\
\hline & Current & .242 & .115 & -.116 & -.344 & .064 & 1.000 & & \\
\hline & $\mathrm{PO}_{4}$ & .553 & -.345 & -.824 & .032 & -.086 & .204 & 1.000 & \\
\hline & $\mathrm{NO}_{3}$ & -.576 & .310 & .562 & .040 & .034 & -.275 & -.619 & 1.000 \\
\hline \multirow{8}{*}{ 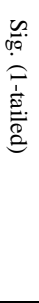 } & DGR & . & & & & & & & \\
\hline & Temperature & .247 & . & & & & & & \\
\hline & Salinity & $.000^{*}$ & .035 & . & & & & & \\
\hline & Brightness & $.039^{*}$ & .326 & .386 & . & & & & \\
\hline & Depth & .353 & .436 & .152 & .007 & . & & & \\
\hline & Current & .127 & .297 & .294 & .050 & .384 & . & & \\
\hline & $\mathrm{PO}_{4}$ & $.003^{*}$ & .049 & .000 & .441 & .345 & .170 & . & \\
\hline & $\mathrm{NO}_{3}$ & $.002 *$ & .070 & .002 & .426 & .438 & & .001 & . \\
\hline
\end{tabular}

significantly correlated at the 0.05 level
Table 3 shows the correlation between oceanographic parameters and the daily growth rate of E. cottonii at the $95 \%$ confidence level. Salinity, brightness, phosphate, and nitrate have significance values below 0.05 , while other parameters do not have a significant correlation. The Pearson correlation value also shows a negative correlation on temperature, salinity, brightness, depth of water, and nitrate while the phosphate parameters and current velocity have a positive correlation. The parameters that are negatively correlated will reduce the daily growth rate of $E$. cottonii if the parameter values increase, while the parameters that positively correlate will increase the daily growth rate of seaweed E. cottonii if the parameter values increase.

\section{Suitability of Seaweed Cultivation Land}

Based on the conformity assessment system for the location of seaweed cultivation and the average results of oceanographic parameters in the field, a score for suitability of the location for seaweed cultivation for each station was obtained. From this value, the final value (Y) was obtained for each station (Table 4). After the final value of each station was obtained, then the interval value of the class of suitability was calculated to determine the class interval of each category, so that the range of values in each class of suitability was obtained. Then the intervals for each suitability class were obtained as follows:

Very suitable category (S1): Y = $90-66$

Less appropriate category (S2): Y $=65-42$

Inappropriate category $(\mathrm{N}): \mathrm{Y}=<42$

Table 4. Final scores for each station

\begin{tabular}{lll}
\hline Station & Final Score (Y) & Class Category \\
\hline 1 & 46.67 & Less appropriate (S2) \\
2 & 51.11 & Less appropriate (S2) \\
3 & 71.11 & Very suitable (S1) \\
4 & 51.11 & Less appropriate (S2) \\
5 & 57.78 & Less appropriate (S2) \\
6 & 55.56 & Less appropriate (S2) \\
\hline
\end{tabular}

Based on the final score on each station, the category of study location was determined as less suitable and very suitable. This condition indicates the limiting factor in the location of seaweed cultivation. Based on the daily growth rates data for 40 days of observation at six stations, the average daily growth rate was above $4 \%$ per day. This condition shows that the existed parameter conditions (Figure 2) can still support the growth of E. cottonii seaweed properly.

\section{Land Completeness Map}

Data on average oceanographic parameters that had been measured during the study were then analyzed spatially using the interpolation method. Interpolation results for each parameter were loaded using a map processing application. The interpolation data was then overlaid to produce a map of suitability for 
E. cottonii cultivation based on oceanographic parameters and daily growth rates of E. cottonii which were measured during the study at the beginning of the dry season (Figure 3).

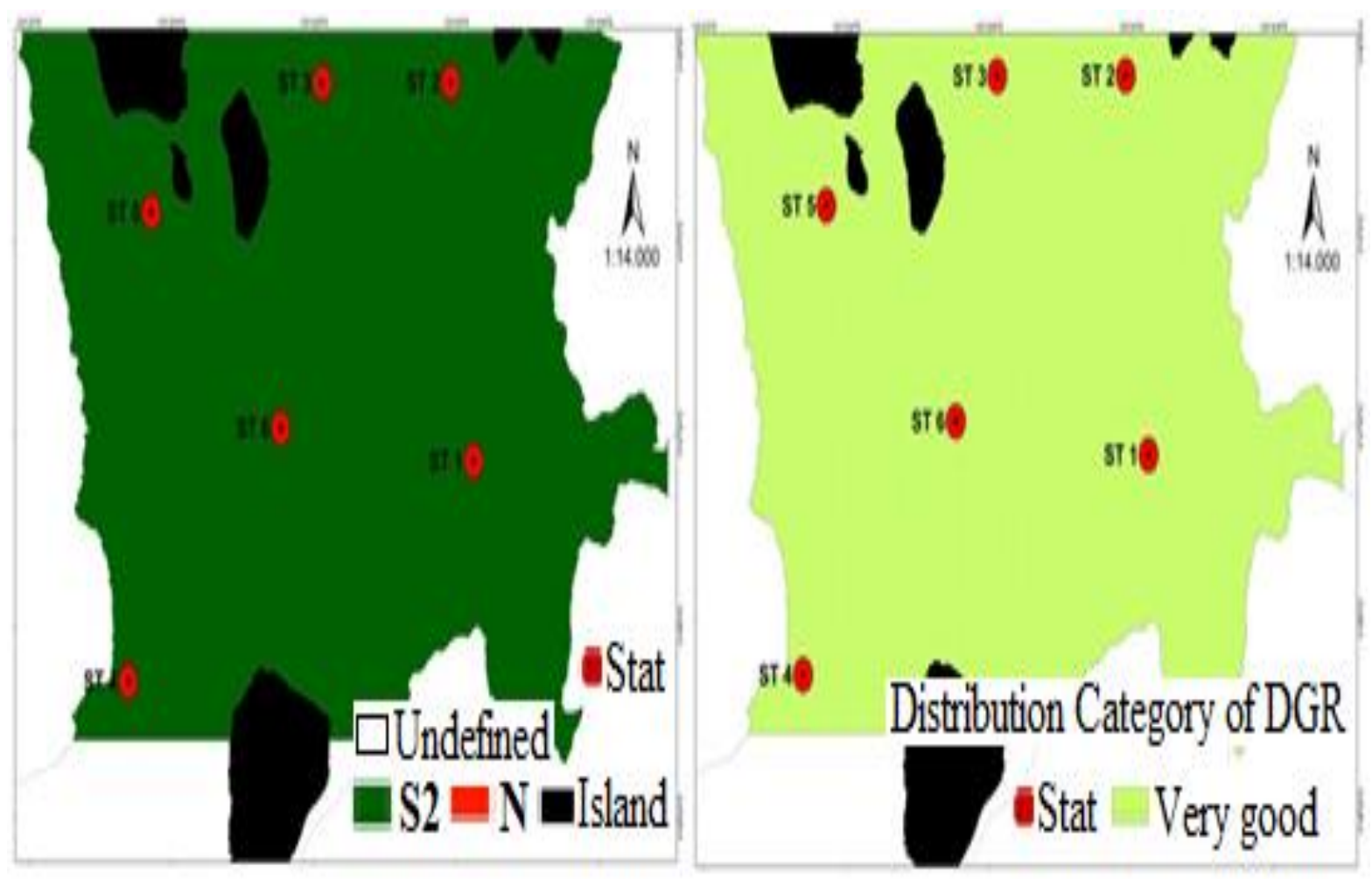

Figure 3. Map of the suitability of seaweed cultivation land in Pacific waters based on (A) oceanographic parameters and (B) daily growth rate measured at the beginning of the dry season

Figure 3 shows differences in class categories based on oceanographic parameters and daily growth rates. Based on existed oceanographic conditions, 99\% of the research locations were fall the class category Less Suitable, while based on the daily growth rate of $E$. cottonii seaweed the entire study location was in the class category Very Suitable.

\section{CONCLUSION}

Based on the results of this study, it can be concluded that:

1. The area of E. cottonii seaweed cultivation in Pasiea waters based on oceanographic parameters, was in Less Suitable Category which covering an area of $1410 \mathrm{Ha}$ and Not Suitable Category for $1 \mathrm{Ha}$ area. In contrary, the analysis based on the daily growth rate of $E$. Cottonii, the entire study site was in the Very Suitable Category and covering an area of 1411 Ha.

2. The dynamics of oceanographic parameters in Pasiea waters were still within the suitable range for the growth of E. cottonii seaweed.

3. Correlation test results indicate that salinity, brightness, phosphate, and nitrate have a significant correlation to the daily growth rate of $E$. cottonii seaweed.

\section{ACKNOWLEDGMENT}

We would like to thank the Halu Oleo University, Faculty of Fisheries and Marine Sciences Testing Laboratory for their support.

\section{REFERENCES}

Ariyati R.W., Syarani, L., \& Arini E., 2007. Analisis Kesesuaian Perairan Pulau Karimunjawa dan Pulau Kemujan Sebagai Lahan Budidaya Rumput Laut Menggunakan Sistem Informasi Geografis. Jurnal Pasir Laut, Vol.3, No.1 Hal: 27- 45

Avianti, E., Nani, H., \& Tuty, H., 2015. Kesesuaian Lahan Budidaya Rumput Laut Eucheuma cottonii di Perairan Tarakan Dengan Faktor Pembatas Variabilitas Enso dan Musim. Jurnal Segara Vol. 11 No. 1 Hal: 13-24

Badan Pusat Statistik (BPS) Kabupaten Buton Utara, 2017. Kabupaten Buton Utara Dalam Angka. CV. Metro Graphia

Darmawati, Niartiningsih A., Rajuddin S., \& Jamaluddin, J., 2016. Analisis Kandungan Karotenoid Rumput Laut Caulerpa sp. yang Dibudidayakan di Berbagai Jarak dan Kedalaman. Seminar Nasional. Lembaga Penelitian dan Pemberdayaan Masyarakat Unmas Denpasar. Bali. 
Hasnawi, Makmur, \& Muidana P., 2013. Analisis Kesesuaian Lahan Budidaya Rumput Laut di Kabupaten Minahasa Utara Provinsi Sulawesi Utara. Dalam Prosiding Forum Inovasi Teknologi Akuakultur, Maros 2013. Hal: 985995

Hermawan D., 2015. Pengaruh Perbedaan Strain Rumput Laut Kappaphycus alvarezii Terhadap Laju Pertumbuhan Spesifik. Jurnal Perikanan dan Kelautan Vol. 5 No.1

Hernanto A.D., Sri Rejeki dan Restina Wisnu Ariyati. 2015. Pertumbuhan Budidaya Rumput Laut (Eucheuma cottonii dan Graciliria sp.) dengan Metode Long Line di Perairan Pantai Bulu Jepara. Journal of Aquaculture Management and Technology Volume 4, No. 2

Jailani A.Q., Endang Y.H., \& Bambang S., 2015. Studi Kelayakan Lahan Budidaya Rumput Laut Eucheuma cottonii di Kecamatan Bluto Sumenep Madura Jawa Timur. Jurnal Manusia Dan Lingkungan Vol. 22, No. 2, Juli 2015. Hal: $211-216$

Rehena F.R., 2009. Produktivitas Biomassa dan Laju Pertumbuhan Rumput Laut Eucheuma cottonii di Perairan Wael Seram Bagian Barat Provinsi Maluku. Jurnal Berk. Penel.Hayati:14 (197201)

Santoso L., \& Yudha T.N., 2008. Pengendalian penyakit ice-ice untuk meningkatkan produksi rumput laut indonesia. Jurnal Saintek Perikanan Vol. 3 No. 2,. Hal: 37-43

Sirajuddin M. , 2009. Informasi Awal Tentang Kualitass Biofisik Perairan Teluk Waworada Untuk Budidaya Rumput Laut (Eucheuma cottonii). Jurnal Akuakultur Indonesia, 8 (1) Hal: $1-10$
Serdiati N. \& Widiastuti I.M., 2010. Pertumbuhan dan produksi rumput laut Eucheuma cottonii pada kedalaman penanaman yang berbeda. Jurnal Media Litbang Sulteng 3 (1), Hal: 21 -26

Selamat M.B., Muhammad F.S., Zainuddin, \& Arniati M., 2015. Aplikasi sistem informasi geografis dan Penginderaan Jauh Satelit Untuk Evaluasi Pemanfaatan Ruang Budidaya Rumput Laut di Pantai Amal, Kota Tarakan, Kalimantan Utara.

Prosiding Simposium Nasional Kelautan dan Perikanan 2. Makassar, 5 Oktober 2015. Universitas Hasanuddin, Makassar, Hal: 164173

SNI 7579.2, 2010. Produksi Rumput Laut Kotoni (Eucheuma cottonii) - Bagian 2: Metode Longline. Badan standarisasi Naional (BSNI).

Syamsuddin R. \& Misbah I., 2018. Pertumbuhan, produksi Biomassa, dan Kadar Karanginan Rumput Laut Kappahycus alvarezii yang Dipupuk dengan Ammonium dan Nitrat Pada Budidaya Sistem Indoor. Fajar Press, Sulawesi Selatan

Tim Perikanan WWF-Indonesia, Boedi Sardjana Julianto \& Badrudin. 2014. Seri Panduan Perikanan Skala Kecil Budidaya Rumput Laut Gracilaria sp. Di Tambak. WWFIndonesia

Wulandari S.R., Sahala H., \& Ruswahyuni, 2015. Pengaruh Arus Dan Substrat Terhadap Distribusi Kerapatan Rumput Laut Di Perairan Pulau Panjang Sebelah Barat Dan Selatan. Diponegoro Journal Of Maquares Management Of Aquatic Resources.Vol 4 No. 3, Hal: 91 98. 